\title{
Levels of Inquiry-Interactive Demonstration: Its Effect on Students' Critical Thinking Ability in Online Learning with the Topic of Waves and Sounds
}

\author{
Siti Nafingah ${ }^{1, a)}$, Mohamad Agung Rokhimawan ${ }^{2, b)}$, Ali Mustadi ${ }^{1, c)}$, \\ Muhammad Nur Wangid ${ }^{1, d)}$ \\ ${ }^{1}$ Primary Education Departement, Postgraduate Program, Universitas Negeri Yogyakarta, Indonesia \\ ${ }^{2}$ Madrasah Ibtidaiyah Teacher Education Departement, FITK, UIN Sunan Kalijaga Yogyakarta, \\ Indonesia \\ a)sitinafingah.2019@student.uny.ac.id, b)rokhimawan78@gmail.com, ${ }^{c}$ ali_mustadi@uny.ac.id, \\ d)m_nurwangid@uny.ac.id
}

\begin{abstract}
This study aims to determine the effect of Levels of Inquiry-Interactive Demonstration on students' critical thinking ability at UIN Sunan Kalijaga Yogyakarta. This research is a quasiexperimental type with a pretest-posttest control group design. The research sample was taken using a cluster sampling technique. The sample consisted of the experimental class (PGMI A) composed of 41 students using the Inquiry-Interactive Demonstration model. The control class (PGMI B) was composed of 41 students using conventional learning models lecture and assignment methods. The data collection technique used was a test through quizizz, google form, observation, and documentation. The data analysis technique used descriptive statistics which were, preceded by a normality test. Hypothesis testing using the T-test. The results showed that the pretest-posttest mean score increased, namely the pre-test 68.49 and the post-test 85.27 with Tcount $11.95>$ Ttable 2.023. Then the results of the sig value. $0.000<0.05$ means that using the Inquiry-Interactive Demonstration model has a significant effect on students' critical thinking abilities on the topic of waves and sound.
\end{abstract}

Keywords: levels of inquiry model, interactive demonstration, critical thinking ability, online learning

\section{INTRODUCTION}

Implementing an online learning system in all Indonesian schools from early childhood to higher education since the beginning of March 2020 is the result of the outbreak of the Covid-19 pandemic. This situation is a big challenge for educators in maximizing online learning. Although students cannot be done learning face-to-face, it must still prioritize the demands of $4 \mathrm{C}$ skills in the 21 st century, which include critical thinking and problem solving, creativity and innovation, communication, and collaboration. One crucial aspect that must be presented during learning activities is critical thinking. Critical thinking is reflective thinking that makes sense and focuses on deciding what to believe or do (Ennis 1993). Referring to Bloom's cognitive taxonomy (Lukitasari, Hasan \& Murtafiah 2019), critical thinking is the highest level, which refers to analyzing, synthesizing, and evaluating. A critical person has skills in answering difficult questions where information is limited and can be explained rationally (Dholo et al. 2019). Someone who thinks critically will be able to answer important problems well and use abstract ideas to model problem solving effectively. In elementary school students, critical thinking 
becomes a motivation to know more about knowledge and be stored in long-term memory (Hu et al. 2016). Besides, there is also a significant relationship between critical thinking and cognitive learning outcomes (Siburian et al. 2019).

Several research results on critical thinking ability in Indonesia show that critical thinking ability is still low. Research conducted Kirana \& Kusairi (2019) shows that the average critical thinking ability of science education study program students in the early semester is only 31.12 , very low categories, and final semester students in the low category 47.06. Several other research results, namely the low critical thinking category score of 36.1 (Rosyidah et al. 2020). Students need to be trained intensively to improve their critical thinking ability and be familiar with questions that stimulate critical thinking ability (Gunawan, Sarwanto \& Nurosyid 2019) (Dholo et al. 2019). Based on the research that has been done, many factors cause low critical thinking ability. The factors include misconceptions, not being used to applying physics concepts in everyday life, needing to get stimuli, difficulty making or identifying assumptions, and having difficulty identifying data.

Educators can practice their students' critical thinking ability in various ways to produce an active learning atmosphere in the classroom. One way is the use of an appropriate learning model that is student-centered. The learning model is a conceptual framework that describes a systematic procedure for organizing learning experiences to achieve learning goals (Trianto 2010). One of the studentcentered learning models that makes students active and develops their critical thinking ability is inquiry learning (Duran \& Dökme 2016). In general, the inquiry is obtaining information through scientific investigation to determine a phenomenon that occurs (Dewey 1938). Learning using the inquiry model is an example of meaningful learning (Sudigdo \& Setiawan 2020). First, students are involved in the assimilation process when combining existing experience and knowledge with new information that is being learned. Second, students modify existing concepts to overcome current problems to bring up new ideas. According to the National Science Education Standards in Wenning (2005) inquiry is an activity of students to develop knowledge and understanding of scientific concepts as scientists learn science about nature.

Wenning developed the inquiry learning model into a multilevel model called the Levels of Inquiry Model. This level of inquiry consists of six levels. The inquiry levels are discovery learning, interactive demonstration, inquiry lessons, lab inquiry, real-world applications, and hypothetical inquiry (Wenning 2005). The six stages are sorted based on the intellectual abilities involved (students) and the controlling party (educators) in learning. Wenning introduced the Level of Inquiry model for science learning. One of them is an interactive demonstration. This learning's primary purpose is to invite students to explain and create hypotheses that involve educators to get, identify, face, and complete alternative conceptions (towards main knowledge). Levels of Inquiry The model in science learning is partly based on John Dewey's learning model, namely experiential learning (Wenning 2011). The use of experiential learning and inquiry practice is directed at increasing the general scientific literacy of students. According to John Dewey, teaching theory must be more closely related to the desired outcome and that the best way to make students more aware and scientifically informed is through experiential learning (Wenning 2011).

Delivering lectures through online media has become the latest modification that the education system in Indonesia has had to do as a result of the current pandemic situation. In the application of online learning based on the survey conducted by Bao (2020), five impact principles must be considered: a) the relevance of online instructional design and learning, b) effective delivery, c) adequate support; d) participation increases the depth of learning, and (e) contingency plans to deal with unexpected online educational platform incidents. All of these are principles that must remain in online learning so that learning remains meaningful. Further findings indicate that essential aspects to be applied in online classes are quality and timely interaction between students and lecturers, the availability of technical support, online class modules, and modifications to accommodate practical class implementation (Deepika 2020). Of course, the role of technology is critical in bridging the learning process. Of the various learning processes carried out in Indonesia, some of which are used, namely the WA group, google classroom, quizizz, khoot, zoom, google form, and many more. Herein lies the innovation made by educators. They must apply the right learning model, make students active, and the essence of learning can be widely absorbed even though education is carried out online. 
Based on some problems described previously, it is necessary to make efforts to innovate an adaptive physics learning model according to the conditions of the non-face-to-face learning system (online learning). The purpose of this study was to determine the effect of the application of levels of the inquiry-interactive demonstration on students' critical thinking ability in learning physics material Waves \& Sounds based on online learning.

\section{METHODS}

This research was a quasi-experimental study with a pretest-posttest control group design. This research was conducted at UIN Sunan Kalijaga, which is located at Jln. Marsda Adisucipto, Yogyakarta in March-May 2020. The subjects in this study were PGMI fourth semester students of advanced science class A and B classes with 82 students taking Waves and Sounds. This study involved two classes: the experimental class or the treated class and the control class or the untreated class. The experiment class (PGMI A) learning was carried out using Levels of Inquiry-Interactive Demonstration learning. In contrast, the control class (PGMI B) was carried out using conventional methods, namely the lecture and assignment methods. The design of the pretest-posttest control group is shown in TABLE 1 (Sugiyono 2011).

TABLE 1. Pretest-Posttest Research Design with Control Group

\begin{tabular}{lccc}
\hline Class & Pre-test & Treatment & Post-test \\
\hline Experiment & $\mathrm{O}_{1}$ & $\mathrm{X}_{1}$ & $\mathrm{O}_{2}$ \\
\hline Control & $\mathrm{O}_{3}$ & $\mathrm{X}_{2}$ & $\mathrm{O}_{4}$ \\
\hline
\end{tabular}

Information :

$\mathrm{X} 1=$ Treatment in experimental class

$\mathrm{X} 2=$ Treatment in control class

$\mathrm{O} 1=$ The ability to think critically at the beginning (pretest) of the experimental class

$\mathrm{O} 2=$ Final critical thinking ability (posttest) of experimental class

$\mathrm{O} 3=$ The control class' pretest critical thinking ability

O4 = Final critical thinking ability (posttest) of the control class

The research instruments used in this study were treatment instruments and measurement instruments. The treatment instruments used were syllabus, lesson plan (RPP), and student worksheets (LKM). Learning is delivered online with the WA group's help and learning videos based on the interactive demonstration learning model. The measurement instrument used was a critical thinking ability test instrument that was validated by two expert validators. The revised validation results were then tested for validity, level of difficulty, distinguishing power, and reliability to determine the critical thinking ability test instrument's appropriateness to be used in the study. The test was conducted by giving ten multiple-choice questions and ten essay questions to students using the quizizz platform and google form to measure critical thinking ability. The data analysis technique in this study uses a quantitative approach. Before analyzing the data, the normality prerequisite test was first carried out. Statistical tests carried out quantitative data analysis. The statistical tests used in making decisions are paired t-test, homogeneity test, and independent sample test. All data analyzes were performed using a statistical program in the form of SPSS. The hypotheses tested in the study are as follows:

$\mathrm{H}_{0}=$ There is no significant difference in students' critical thinking abilities with inquiry-interactive demonstration learning (experimental class) and using the assignment lecture method (control class).

$\mathrm{H}_{1} \quad=\quad$ There is a significant difference in students' critical thinking abilities with inquiryinteractive demonstration learning (experimental class) and using the assignment lecture method (control class). 


\section{RESULTS AND DISCUSSION}

The Inquiry model consists of six inquiry levels, namely discovery learning, interactive demonstration, inquiry lesson, lab inquiry (3 types - guided, bounded, and free), real-world applications, and hypothetical inquiry (Wenning 2005). The interactive demonstration is the second level of learning. The higher the investigation stage, the higher the intellectual ability of the students involved in education. However, educators' lower level of involvement means that students are increasingly active in taking roles during the learning process and scientific investigation. The inquiry hierarchy of the levels of inquiry model and the level of intellectual ability of students and the involvement of educators' role is shown in TABLE 2 (Wenning 2005).

TABEL 2. Hierarki Dasar Levels of Inquiry Models

\begin{tabular}{l|c|c|c|c|c}
\hline $\begin{array}{c}\text { Discovery } \\
\text { Learning }\end{array}$ & $\begin{array}{c}\text { Interactive } \\
\text { Demonstration }\end{array}$ & $\begin{array}{c}\text { Inquiry } \\
\text { Lesson }\end{array}$ & $\begin{array}{c}\text { Imquiry Lab } \\
\text { (3types) }\end{array}$ & $\begin{array}{c}\text { Real-world Applications (2 } \\
\text { types) }\end{array}$ & $\begin{array}{c}\text { Hypothetical Inquiry } \\
\text { (2 types) }\end{array}$ \\
\hline Lower & \multicolumn{2}{c}{ Intellectual Shophistication $\rightarrow$} & \multicolumn{2}{c}{ Higher } \\
\hline Teacher & $\leftarrow$ & Locus of Control $\rightarrow$ & Student \\
\hline
\end{tabular}

Interactive demonstrations generally consist of educators manipulating (demonstrating) scientific equipment and then asking probing questions about what will happen (predictions) or how something might happen (explanation). Educators are tasked with explaining, developing, and asking probing questions, getting responses, asking for further reasons, and helping students reach evidence-based conclusions. Educators will generate prejudices and then confront and resolve whatever is identified. Educators model appropriate scientific procedures at the most basic level, thereby helping students learn implicitly about the inquiry process (Wenning 2005).

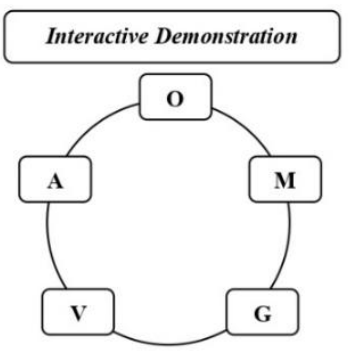

FIGURE 1. Interactive Demonstration Learning Syntax

FIGURE 1. explains that interactive demonstration learning consists of 5 stages, namely observation, manipulation, generalization, verification, and application (Wenning 2011). Furthermore, students and lecturers' activities while carrying out learning using interactive demonstration syntax are described in TABLE 3.

TABLE 3. presents an explanation of each stage of interactive demonstration learning that should be carried out by students and the lecturer. The demonstration activities in question can be in the form of science experiments (practicum), short video clips, or other methods used by educators to demonstrate the material to be conveyed to students. This demonstration process must run interactively, meaning that the lecturer must provide predictions and explanations of how something can happen and open up spaces for interaction with students. Students witness demonstrations and have to play an active role by giving opinions, input, or even constructive criticism (criticizing). According to Ennis, indicators of critical thinking abilities include providing simple explanations (elementary clarification), building basic skills (basic support), concluding (inference), providing further explanations (advanced clarification), developing strategies and tactics (strategy and tactics) (Costa \& Presseisen 1985, p. 54). Based on the indicators of critical thinking skills, a grid of pretest and posttest questions is made.

The main components in education in the industrial era 4.0 are (1) the thinking component includes critical, creative, and problem-solving thinking, and (2) the action component includes communication, collaboration, digital literacy and technological literacy. Critical thinking is undoubtedly one of the essential components in dealing with uncertain changes in the industrial era 4.0, so educators need to teach and develop these abilities to students (Maulana 2018, p. 14). Through critical thinking, a person can give reasons and explain the wrong information to make it right (Lau 2011, p. 3). In the process, 
critical thinking requires openness to thinking, humility, and patience so that it can help a person achieve deep understanding. Critical thinking also provides students opportunities to construct their knowledge (Maulana 2018, p. 14). Through essential thinking ability, students are expected to be responsive and caring in facing and solving problems in their lives.

TABLE 3. Explanation of the Interactive Demonstration Syntax

\begin{tabular}{ll}
\hline \multicolumn{1}{c}{ Syntax } & \multicolumn{1}{c}{ Explanation } \\
\hline Observation & $\begin{array}{l}\text { Students observe a phenomenon that invites their interest and elicits a response. Students } \\
\text { describe what they observe. }\end{array}$ \\
1. Students observe a demo video (about the depth of the sea) displayed by the lecturer on \\
zoom media. \\
2. Student knowledge is explored by conducting questions and answers between students \\
and lecturers.
\end{tabular}

According to Ennis, indicators of critical thinking ability include providing simple explanations (elementary clarification), building basic skills (basic support), concluding (inference), providing further explanations (advanced clarification), developing strategies and tactics (strategy and tactics) (Costa \& Presseisen 1985, p. 54). A person who can use his cognitive skills to think critically and can perform cognitive activities, such as interpretation, analysis, evaluation, inference, explanation, and self-management (Lismaya 2019, p. 8). In this study, the assessment of critical thinking was used by referring to the instrument grid based on the critical indicators of thinking from (Ennis 1993), which are as follows:

TABLE 4. Aspects and Indicators of Critical Thinking Ability

\begin{tabular}{|c|c|}
\hline Aspect & Indicator \\
\hline \multirow{3}{*}{$\begin{array}{l}\text { Give a simple explanation } \\
\text { (Elementary Clarification) }\end{array}$} & Rewrite, mention, and explain. \\
\hline & Focus on questions and analyze arguments. \\
\hline & Understand something critically. \\
\hline \multirow{2}{*}{$\begin{array}{l}\text { Build basic skills } \\
\text { (Basic Support) }\end{array}$} & Observe and consider the results of observations. \\
\hline & $\begin{array}{l}\text { Deducing and inducing, and considering the results of deduction } \\
\text { and induction. }\end{array}$ \\
\hline \multirow{3}{*}{$\begin{array}{l}\text { Conclude } \\
\text { (Inference) }\end{array}$} & Make and consider the value of decisions. \\
\hline & Construct explanations of new knowledge. \\
\hline & Describe the findings based on accurate sources. \\
\hline \multirow{2}{*}{$\begin{array}{l}\text { Provide further explanation } \\
\text { (Advanced Clarification) }\end{array}$} & Determines action. \\
\hline & Justify or calculate with accuracy. \\
\hline \multirow{2}{*}{$\begin{array}{l}\text { Devise strategies and tactics } \\
\text { (Strategy and Tactics) }\end{array}$} & Rewrite, mention, and explain. \\
\hline & Focus on questions and analyze arguments. \\
\hline
\end{tabular}


This study used two classes by comparing the results before treatment (pre-test data) and when what gave treatment (post-test data). The pre-test data is given when the learning to be used in the research has not been carried out. At the next meeting, the research class was given treatment using the Interactive Demonstration learning model. The material used in this research is Waves \& Sounds. The test of critical thinking abilities on the wave $\&$ sound material is quantitatively based on the pre-test and can see post-test data in TABLE 5 .

TABLE 5. Results of Quantitative Analysis of Critical Thinking Ability

\begin{tabular}{lccccc}
\hline \multicolumn{7}{c}{ Descriptive Statistics } \\
\hline & $\mathrm{N}$ & Minimum & $\mathrm{m}$ & Mean & Deviation \\
\hline Pre-Test Experiment & 41 & 60 & 82 & 68.49 & 6.128 \\
\hline Post-Test Experiment & 41 & 76 & 98 & 85.27 & 6.046 \\
\hline Pre-Test Control & 41 & 55 & 80 & 67.10 & 6.164 \\
\hline Post-Test Control & 41 & 72 & 88 & 79.61 & 4.521 \\
\hline Valid N (listwise) & 41 & & & & \\
\hline
\end{tabular}

Based on the data from the quantitative analysis of critical thinking abilities in TABLE 4, What can see that the average value of critical thinking abilities in learning, from before and after being treated, both in the experimental group and the control group, seemed to have increased. In the experimental group, the average pretest score was 68.49 , then treated using an interactive demonstration learning model, which resulted in an average post-test score of 85.27. Furthermore, in the data analysis results in the control group, the pretest's mean value was 68.24 , then treated using a conventional learning model that resulted in an average post-test score of 79.76. Based on the data, the comparison between the two groups shows that the interactive demonstration model is a more appropriate learning model to help students improve their critical thinking abilities. Good essential capabilities of thinking will help students solve physics problems, especially those covering Waves \& Sounds, either in the form of questions or in the application of everyday life.

Furthermore, the normality test was carried out. The normality test is a prerequisite test as a basis for conducting statistical tests of the paired t-test. In the normality test, what will know whether the data obtained comes from normally distributed data or not? The normality test was carried out in both classes up to the experimental class or the control class on the pretest data and post-test data. The normality test results in the experimental class obtained a pretested data significance value of $0.061>$ 0.05 , which means that the data is normally distributed and the post-test data shows a significance value of $0.147>0.05$, which means that the data is normally distributed. In the control class, the pretest data significance value is $0.071>0.05$, which means the data is normally distributed, and the post-test data shows a significance value of $0.095>0.05$, which means that the data is normally distributed. The overall results show that the four data are normally distributed to perform the statistical paired t-test. The results of the analysis of the normality test can be seen in TABLE 6 .

TABLE 6. Results of Normality Test Analysis

\begin{tabular}{|c|c|c|c|c|c|}
\hline & \multirow[b]{2}{*}{ Class } & \multicolumn{3}{|c|}{ Kolmogorov-Smirnov $^{\mathrm{a}}$} & \multirow[t]{2}{*}{ Ket. } \\
\hline & & Statistic & $\mathrm{df}$ & Sig. & \\
\hline \multirow{4}{*}{$\begin{array}{l}\text { Critical } \\
\text { Thinking } \\
\text { Ability }\end{array}$} & Pre-Test Experiment (ID) & .134 & 41 & .061 & Normally Distribution \\
\hline & Post-Test Experiment (ID) & .120 & 41 & .147 & Normally Distribution \\
\hline & Pre-Test Control (Conventional) & .132 & 41 & .071 & Normally Distribution \\
\hline & Post-Test Control (Conventional) & .127 & 41 & .095 & Normally Distribution \\
\hline
\end{tabular}

Furthermore, the paired t-test calculation is carried out to find out whether there is a difference when before being given treatment and after being given treatment in the form of the application of the interactive demonstration learning model in the experimental class and the conventional learning model in the control class. Paired t-test was then analyzed on pretest data and posttest data. The results of the paired t-test on the pretest and posttest data can be seen in TABLE 7. 
TABLE 7. Results of Paired t Test Analysis

\begin{tabular}{|c|c|c|c|c|c|c|c|c|c|}
\hline & & \multicolumn{5}{|c|}{ Paired Differences } & \multirow[t]{3}{*}{$\mathrm{t}$} & \multirow[t]{3}{*}{ df } & \multirow[t]{3}{*}{ Sig. (2-tailed) } \\
\hline & & \multirow[b]{2}{*}{ Mean } & \multirow{2}{*}{$\begin{array}{c}\text { Std. } \\
\text { Deviation } \\
\end{array}$} & \multirow{2}{*}{$\begin{array}{l}\text { Std. } \\
\text { Error } \\
\text { Mean }\end{array}$} & \multicolumn{2}{|c|}{$\begin{array}{c}95 \% \text { Confidence } \\
\text { Interval of the } \\
\text { Difference }\end{array}$} & & & \\
\hline & & & & & Lower & Upper & & & \\
\hline Pair 1 & $\begin{array}{l}\text { Pre-Test } \\
\text { Experiment - } \\
\text { Post-Test } \\
\text { Experiment } \\
\end{array}$ & -16.780 & 4.751 & .742 & -18.280 & -15.281 & -22.614 & 40 & .000 \\
\hline Pair 2 & $\begin{array}{l}\text { Pre-Test } \\
\text { Control - Post- } \\
\text { Test Control }\end{array}$ & -12.512 & 7.187 & 1.122 & -14.781 & -10.244 & -11.147 & 40 & .000 \\
\hline
\end{tabular}

After obtaining the paired t-test analysis results in TABLE 7 based on the pre-test and post-test data in the experimental class with a significance value of $0.000<0.05$ so that $\mathrm{H} 0$ is rejected, it means that there is a significant difference between the pre-test and post-test mean scores. The difference in the paired t-test results shows that students' critical thinking abilities are getting better in learning the Waves \& Sounds material. So, this proves that the interactive demonstration learning model has a strong enough influence on students' critical thinking ability.

TABLE 8. Homogeneity Test Results

\begin{tabular}{llcrrr}
\hline & & Levene Statistic & df1 & df2 & \multicolumn{1}{c}{ Sig. } \\
\hline Critical & Based on Mean & 2.818 & 1 & 80 & .097 \\
\cline { 2 - 6 } $\begin{array}{l}\text { Thinking } \\
\text { Ability }\end{array}$ & Based on Median & 2.218 & 1 & 80 & .140 \\
\cline { 2 - 6 } & $\begin{array}{l}\text { Based on Median and with } \\
\text { adjusted df }\end{array}$ & 2.218 & 1 & 69.524 & .141 \\
\cline { 2 - 7 } & Based on trimmed mean & 2.702 & 1 & 80 & .104 \\
\hline
\end{tabular}

Based on the homogeneity test results in TABLE 8, it is known that the value of significance (Sig.) Based on Mean is $0.097>0.05$, so it can be concluded that the variance of the post-test data for the experimental class and the post-test control class is the same or homogeneous.

TABLE 9. Independent Samples Test Results

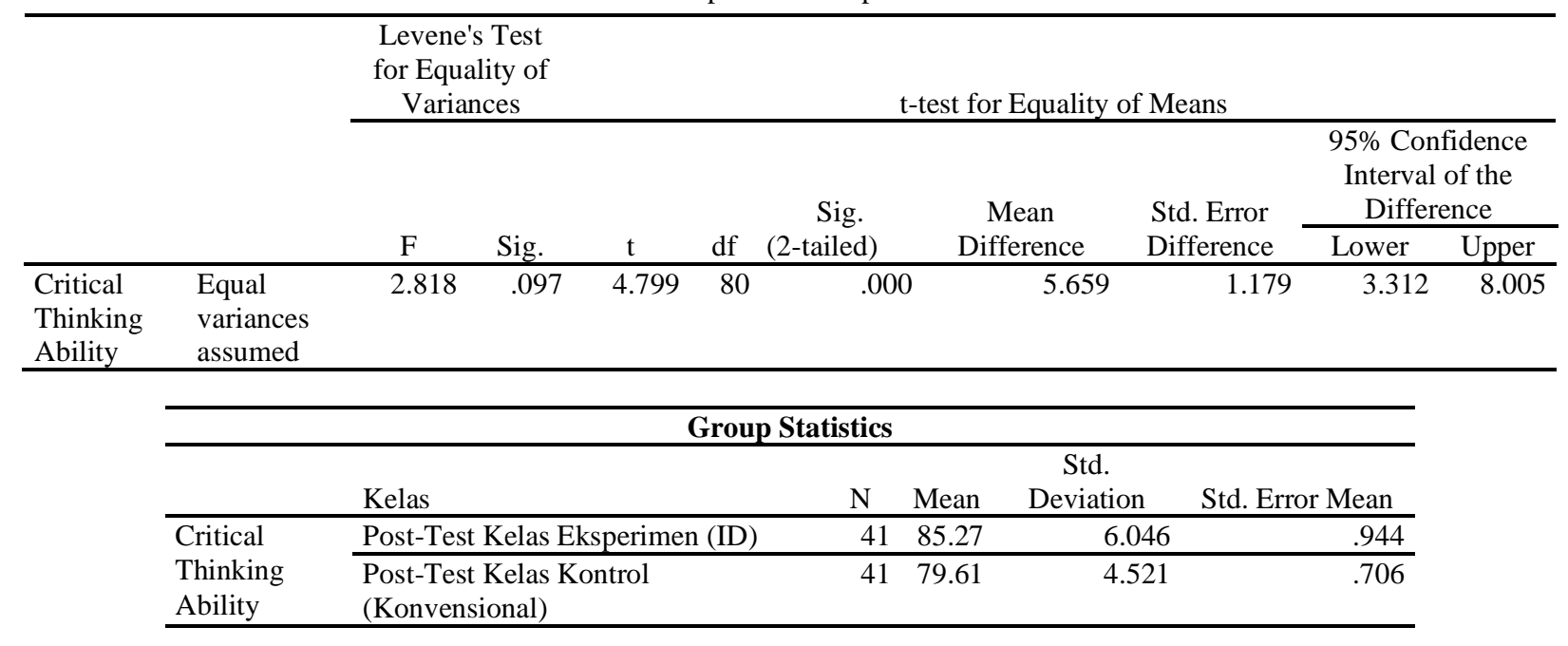

Based on the results of the independent sample test in Table 9, the Sig value is obtained. (2-tailed) of $0.000<0.05$, so it can be concluded that there is a difference in students' average critical thinking ability between the use of interactive demonstration learning models and conventional learning models. The results showed that the interactive demonstration learning model had an influence on the critical thinking ability of 41 PGMI A students in the fourth semester of the Advanced Science subject at UIN Sunan Kalijaga Yogyakarta. The level learning model's influence of the roving students' critical thinking ability is in a strong category. 
TABEL 9. Result Description Statistics

\begin{tabular}{llcccc}
\hline \multicolumn{7}{c}{ Paired Samples Statistics } \\
\hline Pair 1 & Mean & N & Std. Dev & Std. Error Mean \\
\cline { 2 - 6 } & Pre-Test Experiment & 68.49 & 41 & 6.128 & .957 \\
\hline
\end{tabular}

100

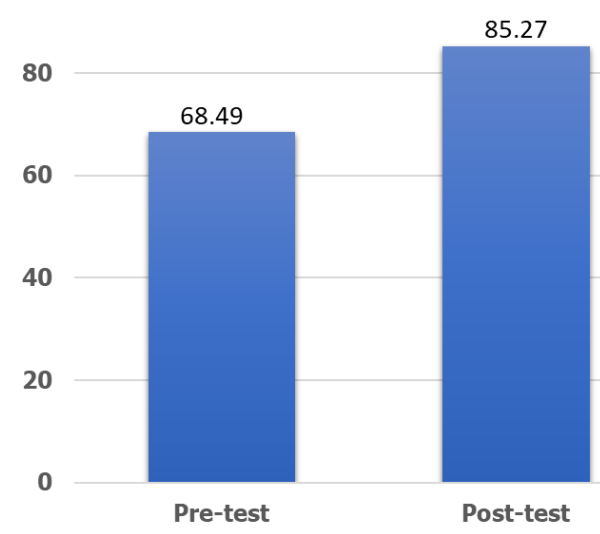

FIGURE 2. Increase in Students' Pretest-Posttest Average Score

In the experimental class with an interactive demonstration learning model, it can be seen that the average post-test minus the pre-test average is obtained $t$-count $=16.78$. Based on Table 7 and Figure 2 , it can be seen that there is an increase in the average pre-test and post-test scores in the experimental class. Furthermore, in more detail, the following shows the percentage increase in the average pretestposttest score of indicator students' critical thinking abilities in FIGURE 3.

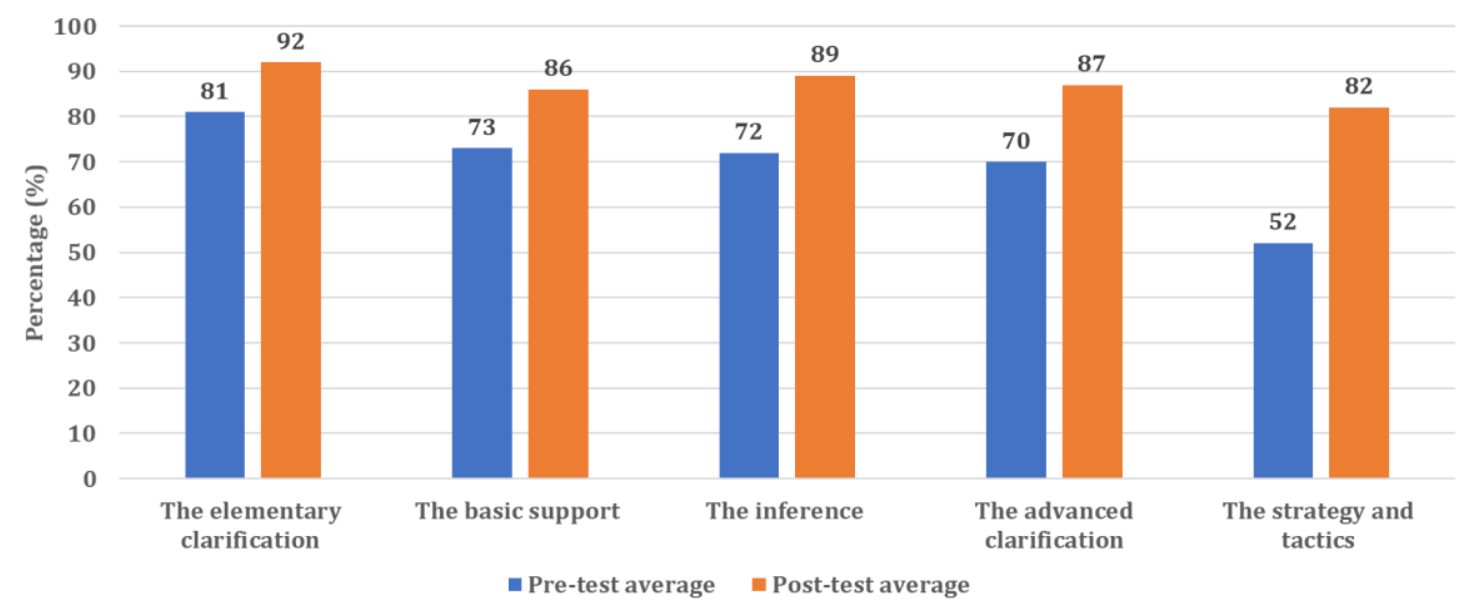

FIGURE 3. Percentage of Students' Pretest-Posttest Average Score Increase for each Indicator

Based on FIGURE 3, the percentage of increase in the average score of indicator students' critical thinking abilities is obtained:

- The elementary clarification indicator, showing an average pretest score of $81 \%$, while the post-test score is $92 \%$.

- The basic support indicator shows an average pretest score of $73 \%$, while the post-test score is $86 \%$.

- The inference indicator shows an average pretest score of $72 \%$, while the post-test score is $89 \%$.

- The advanced clarification indicators, showing an average pretest score of $70 \%$, while the post-test score is $87 \%$.

- The strategy and tactics indicators showed an average pretest score of $52 \%$, while the posttest score was $82 \%$. 
So seen from the increase in the percentage of indicators, it can be interpreted that there is an increase in critical thinking abilities as seen from the increase in the average percentage of post-test scores after learning using interactive demonstrations.

The results obtained in this study are following previous research on the use of interactive demonstration learning models. It is said that the competence to explain scientific phenomena and the competence to interpret scientific data and evidence has increased significantly (Arief \& Utari 2015), and learning outcomes have increased (Sulistiawan, Sumardi \& Berman 2017). Interactive learning when online learning requires technology-based media that is capable of transferring information and can be a means of connecting communication between lecturers and students. One of the active learning models that has been carried out, namely learning using the joyful-inquiry interactive demonstration model assisted by android games, can improve student cognitive learning outcomes on the material of the human respiratory system (Mustikasari, Suwono \& Farhania 2020). Interactive demonstration learning with formative web assessment can improve students' critical thinking skills in static flow material (Harizah, Kusairi \& Latifah 2020). Another study on understanding the dynamics of student involvement in scientific inquiry (inquiry) in online learning (Jaber, Hufnagel \& Radoff 2019). In this study, it was stated that even though it minimizes teachers' role in online learning, learning is still oriented towards student activity in conducting inquiry activities. Based on these three previous studies, the researcher conducted research on the effect of inquiry-interactive demonstration on critical thinking ability using online learning media and answering the research hypothesis that there are significant differences in students' critical thinking abilities with inquiry-interactive demonstration learning (experimental class) and using the lecture assignment method (control class).

\section{SUMMARY}

Based on the discussion and research results that have been described, it can be concluded that the Level of Inquiry-Interactive Demonstration model can help improve critical thinking abilities. Especially the topic of Waves and Sounds in fourth-semester PGMI students on the Advanced Science subject of UIN Sunan Kalijaga Yogyakarta online learning. The results showed that the pretest-posttest mean score increased, namely at pre-test 68.49 and post-test 85.27 with the results of t-count $11.955>$ t-table 2.023 and the result of sig. $0.000<0.05$. This means that the use of the Inquiry-Interactive Demonstration model has a significant effect on critical thinking ability. The increase in critical thinking ability can also be seen from the increase in the average percentage of students' pre-test posttest scores on the five aspects of critical thinking indicators used as references when making questions. The five aspects of critical thinking ability used as references include elementary clarification, basic support, inference, advanced clarification, and strategy and tactics. Besides, compared with conventional learning models, namely the lecture and assignment methods, interactive demonstration results are more effective.

\section{REFERENCES}

Arief, MK \& Utari, S 2015, 'Implementation of Levels of Inquiry on Science Learning To Improve Junior High School Student'S Scientific Literacy', Jurnal Pendidikan Fisika Indonesia, vol. 11, no. 2, pp. 117-25.

Bao, W 2020, 'COVID -19 and online teaching in higher education: A case study of Peking University', Human Behavior and Emerging Technologies, vol. 2, no. 2, pp. 113-15.

Costa, AL \& Presseisen, BZ 1985, 'Glossary of Thinking Skill, in A.L. Costa (ed)', Developing Minds: A Resource Book for Teaching Thinking, ASCD, Alexandria.

Deepika, N 2020, 'The impact of online learning during COVID-19: students' and teachers' perspective', The International Journal of Indian Psychology, vol. 8, no. 2, pp. 784-93.

Dewey, J 1938, 'Logic: The Theory of Inquiry', in Henry Holt and Company, New York. 
Dholo, TF, Firman, H, Kaniawati, I \& Rusdiana, D 2019, 'Profile of critical thinking skills of preservice physics teachers: A preliminary study', Journal of Physics: Conference Series, vol. 1157, no. 3, pp. 1-6.

Duran, M \& Dökme, I 2016, 'The effect of the inquiry-based learning approach on student's criticalthinking skills', Eurasia Journal of Mathematics, Science and Technology Education, vol. 12, no. 12, pp. 2887-908.

Ennis, RH 1993, 'Critical thinking assessment', Theory Into Practice, vol. 32, no. 3, pp. 179-186.

Gunawan, YY, Sarwanto \& Nurosyid, F 2019, 'The analysis of students' critical thinking skill through ethnoscience instruction integrated on the topic of magnetic field', AIP Conference Proceedings, vol. 2194, December.

Harizah, Z, Kusairi, S \& Latifah, E 2020, 'Student's critical thinking skills in interactive demonstration learning with web based formative assessment', Journal of Physics: Conference Series, vol. 1567, no. 4.

Hu, W, Jia, X, Plucker, JA \& Shan, X 2016, 'Effects of a Critical Thinking Skills Program on the Learning Motivation of Primary School Students', Roeper Review, vol. 38, no. 2, pp. 70-83.

Jaber, LZ, Hufnagel, E \& Radoff, J 2019, 'This is Really Frying My Brain!: How Affect Supports Inquiry in an Online Learning Environment', Research in Science Education.

Kirana, IE \& Kusairi, S 2019, 'Profil Kemampuan Berpikir Kritis Mahasiswa Program Studi Pendidikan IPA dalam Kasus Grafik Kinematika Satu Dimensi', Jurnal Pendidikan: Teori, Penelitian, dan Pengembangan, vol. 4, no. 3, pp. 363-68.

Lau, JYF 2011, 'An Introduction to Critical Thinking and Creativity: think More, Think Better', John Wiley And Sons Inc, New Jersey.

Lismaya, L 2019, 'Berpikir Kritis \& PBL (Problem Based Learning)', Media Sahabat Cendekia, Surabaya.

Lukitasari, M, Hasan, R \& Murtafiah, W 2019, 'Using critical analysis to develop metacognitive ability and critical thinking skills in biology', Jurnal Pendidikan Biologi Indonesia, vol. 5, no. 1, pp. 151158.

Maulana 2018, 'Dasar-dasar Konsep Peluang: Sebuah Gagasan Pembelajaran dengan Pendekatan Metakognitif', UPI Press, Bandung.

Mustikasari, VR, Suwono, H \& Farhania, K 2020, 'Improving students' science learning outcomes through joyful-inquiry interactive demonstration assisted by game android', AIP Conference Proceedings, vol. 2215, April.

Rosyidah, ND, Kusairi, S, Taufiq, A \& Affriyenni, Y 2020, 'Profile of students' critical thinking processes on the topics of Hydrostatic Pressure and Archimedes' principle', Journal of Physics: Conference Series, vol. 1511, no. 1.

Siburian, J, Corebima, AD, Ibrohim \& Saptasari, M 2019, 'The correlation between critical and creative thinking skills on cognitive learning results', Eurasian Journal of Educational Research, vol. 2019, no. 81, pp. 99-114.

Sudigdo, A \& Setiawan, B 2020, 'Level of Inquiry in Senior High School Central Java, Indonesia', Journal of Xi'an University of Architecture \& Technology, vol. XII, no. V, pp. 2838-845.

Sugiyono 2011, 'Metode Penelitian Kualitatif, Kuantitatif dan R\&D', Alfabeta, Bandung.

Sulistiawan, F, Sumardi, K \& Berman, ET 2017, 'Penerapan Model Pembelajaran Levels of Inquiry untuk Meningkatkan Hasil Belajar Siswa SMK', Journal of Mechanical Engineering Education, vol. 4 , no. 1 , p. 41.

Trianto 2010, 'Mengembangkan Model Pembelajaran Tematik', PT Prestasi Pustaka, Jakarta. 
Wenning, CJ 2005, 'Levels of inquiry: Hierarchies of pedagogical practices and inquiry processes', Journal of Physics Teacher Education Online, vol. 2, no. 3, pp. 3-11.

Wenning, CJ 2011, 'The Levels of Inquiry Model of Science Teaching', J. Phys. Tchr. Educ. Online, vol. 6, no. 2, pp. 9-16. 
